\title{
Persepsi Generasi Z Terhadap Pengaruh Media Sosial dalam Intensi Pembelian Makanan Vegetarian ala Korea Pada Bisnis Rice Bowl In.yo
}

\author{
Marcella Amanda Genady ${ }^{\mathrm{a}, 1^{*}}$, Cynthia Michellita ${ }^{\mathrm{b}, 2}$ \\ ab Program Studi Pariwisata, Fakultas Pariwisata, Universitas Ciputra Surabaya, Citraland CBD Boulevard, Made, \\ Sambikerep, Surabaya, 67219, Indonesia \\ ${ }^{1}$ mamandagenady@student.ciputra.ac.id; ${ }^{2}$ cmichellita@student.ciputra.ac.id \\ * penulis korespondensi
}

\begin{abstract}
The rapid change in food and beverage trends is a big challenge for the culinary industry. With the COVID-19 pandemic, a trend for vegetarian food and healthy food has begun to emerge, besides that Korean food is also increasingly favored by Generation Z. This study aims to determine the perceptions of Generation Z, especially consumers of In.yo, a Korean-themed local business that provides various food variant with vegetative protein that is cooked and seasoned with Korean flavors, on the influence of social media in purchasing Korean-style vegetarian food, even though consumers do not adopt any kind of vegetarian lifestyle. The research was conducted online to four In.yo consumers in the cities of Surabaya, Jombang, and Samarinda. From this research, it can be concluded that Generation Z, although they have very low knowledge of vegetarian types and vegetable protein as an alternative to meat, have the intention to buy Koreanstyle vegetarian food because they are curious to try because they see advertisements on social media, they want to lose weight., and because the price is cheaper than the menu with chicken as the protein. So In.yo's efforts to educate Generation $Z$ about the vegetarian diet through social media, as well as provide vegetarian food choices, have had a major impact on changing Generation Z's perception of Korean-style vegetarian food.
\end{abstract}

Keywords : Korean food, social media, vegetarian, Z generations

\begin{abstract}
ABSTRAK
Pesatnya perubahan tren makanan dan minuman menjadi tantangan besar bagi industri kuliner. Dengan adanya pandemi COVID-19, mulai muncul tren makanan vegetarian dan makanan sehat, selain itu makanan Korea juga kian digemari oleh Generasi Z. Penelitian ini bermaksud untuk mengetahui persepsi Generasi Z khususnya konsumen In.yo, sebuah bisnis lokal bertemakan Korea yang menyediakan berbagai varian makanan dengan protein nabati yang diolah dengan cita rasa ala Korea, terhadap pengaruh media sosial dalam intensi pembelian makanan vegetarian ala Korea, meskipun konsumen tidak menjalankan pola hidup vegetarian jenis apapun. Penelitian dilakukan secara daring pada 4 (empat) konsumen In.yo di kota Surabaya, Jombang, dan Samarinda. Dari penelitian ini dapat disimpulkan bahwa Generasi $\mathrm{Z}$ meskipun memiliki pengetahuan yang sangat rendah mengenai jenis-jenis vegetarian maupun protein nabati sebagai alternatif daging, memiliki intensi pembelian makanan vegetarian ala Korea karena rasa penasaran ingin mencoba karena melihat iklan yang ada di media sosial, ingin menurunkan berat badan,serta karena harga yang lebih murah dibandingkan dengan menu berprotein daging ayam. Sehingga usaha In.yo untuk mengedukasi Generasi $Z$ mengenai pola makan vegetarian melalui media sosial, serta menyediakan pilihan makanan vegetarian memiliki pengaruh besar untuk mengubah persepsi Generasi $\mathrm{Z}$ terhadap makanan vegetarian ala Korea.
\end{abstract}

Kata Kunci : generasi Z, makanan Korea, media sosial, vegetarian 


\section{Pendahuluan}

Menurut penelitian Maslow (1984), makanan dan minuman merupakan kebutuhan paling dasar manusia untuk mempertahankan hidup secara fisik. Bagi industri kuliner, tantangan terbesar adalah kemampuan adaptasi pada tren makanan dan minuman global, diikuti pula dengan dinamika tren konsumen yang pesat. Kota Surabaya sebagai contoh utamanya, merupakan salah satu kota dengan perkembangan bisnis kuliner terpesat di Indonesia dengan pertumbuhan yang mencapai yang telah mencapai $20 \%$ pada kuartal pertama 2019. Penelitian yang dilakukan oleh Gojek Indonesia menyatakan bahwa dari seluruh bisnis baru yang bermunculan, sekitar $40 \%$ diantaranya dikelola oleh anak muda dengan usia Milenial hingga Generasi Z (Anonim, 2020). Hal ini menjelaskan pula alasan mengapa begitu cepatnya pergantian tren makanan di Surabaya. Menurut Asosiasi Perusahaan Jasaboga Indonesia (APJ), hanya pada tahun 2018 sektor kuliner Indonesia tumbuh hingga $12,7 \%$ setiap tahunnya dan diprediksikan akan terus meningkat (Trihendrawan, 2019). Melihat pesatnya perubahan pola konsumsi generasi $\mathrm{Z}$ saat ini terutama karena pandemi COVID-19, terdapat trend dimana masyarakat mulai memperhatikan kesehatan dengan memilih makanan vegetarian maupun makanan sehat. Diperkirakan pasar pangan nabati global akan mencapai 38,4 miliar dolar Amerika Serikat pada 2025. Di Amerika Serikat, jumlah produk nabati yang tersedia meningkat 29 persen antara 2017 hingga 2019 (Susilawati, 2020). Selain itu, salah satu makanan kekinian yang kerap kali menjadi pilihan masyarakat saat ini adalah makanan ala Korea terutama dengan maraknya Korean Wave. Fenomena Korean Wave ini banyak menimbulkan fanatisme, sehingga perkembangannya pesat, terutama di kalangan Generasi Z. Fenomena ini, secara tidak langsung mengubah gaya hidup penggemar Korea, salah satunya adalah pola makan dan preferensi makanan. (Putri dkk,. 2019).

Dengan meningkatnya ketertarikan Generasi $\mathrm{Z}$ terhadap makanan vegetarian, makanan sehat dan makanan ala Korea, mulai banyak bermunculan restoran maupun usaha penyedia makanan online yang menyediakan makanan tersebut. Vegetarian sendiri merupakan sebutan bagi orang yang hanya mengkonsumsi makanan dari tumbuh-tumbuhan. Pola makan ini bukan merupakan ajaran dari agama tertentu saja, namun lebih disebabkan pada keyakinan bahwa makanan vegetarian adalah makanan yang memiliki dampak baik bagi kesehatan tubuh manusia (Padmasuri, 2015). Jenis vegetarian sendiri ada sangat banyak, bahkan ada pula vegetarian yang masih mengkonsumsi unggas, dan hewan laut, dan hanya memiliki pantangan daging merah saja.

Pola makan vegetarian memberikan berbagai manfaat bagi kesehatan seperti menjaga kesehatan jantung, mencegah kanker, membantu menurunkan berat badan, menguatkan tulang, membantu proses metabolisme, dan terhindar dari racun lemak hewani (Padmasuri, 2015). Namun, meningkatnya ketertarikan masyarakat dengan makanan sehat dan makanan vegetarian, belum tentu menganut pola makan tersebut, karena banyak faktor yang menyebabkan seseorang tertarik untuk makan makanan vegetarian, antara lainnya adalah mengikuti trend, ingin hidup sehat, adanya rasa penasaran dan keingintahuan terhadap pola makan vegetarian (Hendrika, 2011). Maka dari itu bersamaan dengan makanan sehat, dan makanan vegetarian, makanan ala korea juga menjadi marak. Makanan Korea sendiri merupakan makanan yang dimasak dengan teknik dan cita rasa orang Korea. Biasanya 
dibumbui dengan minyak wijen, kecap, garam, bawang putih, dan gochujang. Makanan ini banyak digemari oleh Generasi Z seturut meningkatnya ketertarikan Generasi Z pada budaya Korea melalui musik dan drama Korea.

Generasi Z yang saat ini merupakan generasi dengan populasi terbanyak di Indonesia, berdasarkan survei Alvara Research Centre yang dikutip oleh Berita Satu, menyatakan bahwa $80.5 \%$ pengguna internet saat ini didominasi oleh Generasi Z, generasi ini menjadi generasi yang peka pada tren global dan Generasi $Z$ dapat dikatakan sebagai generasi yang saat ini paling berpengaruh terhadap perubahan tren makanan saat ini (Fer, 2020). Maka tidak mengejutkan bahwa seringkali Generasi Z terpapar pada tren kuliner global yang menyebabkan makanan modern kerap kali lebih diminati. Saat ini salah satu jenis makanan yang paling diminati Generasi $\mathrm{Z}$ adalah makanan ala Korea karena besarnya budaya Korea yang tengah populer di kalangan Generasi Z.Generasi $\mathrm{Z}$ adalah generasi yang mencapai usia produktif di tahun 2030, dan ini merupakan bonus demografis bagi bangsa Indonesia. Berdasarkan buku berjudul "Generasi Z \& Revolusi Industri 4.0" Generasi yang disebut juga iGeneration, generasi net atau generasi internet sudah dihadapkan dengan teknologi dan akrab dengan gadget sejak dini, secara tidak langsung hal tersebut mempengaruhi perilaku dan psikologis Generasi Z. Selain fasih teknologi dan memiliki jiwa sosialisasi yang tinggi, Generasi $Z$ juga memiliki karakteristik cepat berpindah dari satu pemikiran ke pemikiran lainnya atau disebut juga fast switcher (Wijoyo, 2020). Sebagai konsumen, Generasi Z dianggap potensial dan layak untuk menentukan pilihannya sendiri. Dengan kefasihan Generasi $Z$ terhadap teknologi, dalam proses pembelian pun, mayoritas Generasi $\mathrm{Z}$ lebih memilih untuk melakukan belanja online melalui aplikasi karena dianggap lebih mudah dan cepat. Berdasarkan penelitian yang dilakukan pada Generasi Z di Hungaria pada tahun 2016 silam, Hidvégi dan Kelemen-Erdős pada tahun 2016 menemukan bahwa sebanyak 99,34\% Generasi Z menggunakan internet tiap hari, sebanyak 82,1\% menyatakan bahwa sumber informasi pembelian adalah internet dan sebanyak 30,4\% lebih suka belanja lewat internet. Berbagai bisnis olahan minuman modern pun, juga mulai marak, dan memiliki banyak peminat, terutama dengan pembelian melalui aplikasi seperti Go-food dan Grabfood, maupun pembelian dengan sistem pre order.

Dengan Generasi Z sebagai salah populasi terbesar di Indonesia saat ini, pemasaran dan pembagian informasi untuk memperkenalkan brand melalui media sosial menjadi pilihan yang banyak dilakukan oleh bisnis makanan dan minuman. Menurut Salvatore (2005) pemasaran media sosial adalah media pemasaran yang dilakukan online yang melibatkan masyarakat untuk membentuk pasar di dunia maya. Dalam melakukan pemasaran dalam media sosial, terdapat tiga variabel yang mendukung, yakni brand exposure, customer engagement, dan electronic word of mouth. Media sosial memiliki banyak peran dalam pemasaran, hal ini juga disampaikan oleh Neti (2011), bahwa media sosial dpat memberikan identitas terhadap produk yang ditawarkan, dapat menjadi alat penelitian kebutuhan konsumen, dapat menjadi alat komunikasi dan perekat hubungan bagi pemasar dan konsumen, serta dapat membangun customer engagement. Saat ini, terutama dengan adanya pandemic COVID-19 yang semakin membatasi masyarakat untuk bepergian, media sosial menjadi pasar dan toko yang dapat diakses oleh konsumen kapanpun dan dimanapun. Maka dari itu, penting sekali untuk brand untuk menunggah berbagai konten 
yang berhubungan dengan brand tersebut, sehingga konsumen dan calon konsumen dapat mengenalinya. Salah satu bentuk yang sedang marak dibuat adalah microblog. Microblogging adalah suatu bentuk blog yang memungkinkan oengguna untuk menulis teks singkat dan menunggahnya untuk dilihat semua orang atau sekelompok orang terbatas (Sawyer, et.al., 2001). Salah satu media yang saat ini banyak digunakan adalah Instagram. Melalui media sosial Instagram, brand dapat menceritakan banyak hal, baik mengenai produknya, maupun mengenai hal-hal unik yang dimiliki oleh brand tersebut. Segala hal ini perlu dilakukan untuk mendapatkan kesadaran konsumen, yang merupakan cara individu atau kelompok memilih, membeli, menggunakan, dan membuang produk atau jasa dalam rangka memenuhi kebutuhannya, hal ini berhubungan dengan pengetahuan konsumen terhadap produk yang akan dibelinya, serta permasalahan yang terkait dengan produk (Sumarwan, 2002.).

Dengan fakta diatas, maka semakin marak bisnis makanan dan minuman yang bermunculan, bahkan hanya berniaga secara online. Salah satu contoh bisnis yang menyediakan berbagai varian makanan yang menjadi ketertarikan Generasi Z saat ini adalah bisnis makanan berbasis online, yaitu "In.yo". In.yo merupakan bisnis makanan sehat bertema Korea dan Jepang, yang tak hanya menawarkan berbagai menu makanan ala Korea dan Jepang, namun juga menawarkan berbagai pilihan vegetarian dengan cita rasa yang sama, yang kemudian dikemas dalam bentuk rice bowl. Dalam bahasa Jepang, arti In'yõ adalah tanda kutip ( “). Tanda kutip, atau tanda petik, biasanya digunakan pada kata maupun kalimat yang diambil dari sumber lain, dan dapat juga digunakan pada untuk menggambarkan bahwa kata yang dituliskan berbeda dengan arti harafiahnya. Karena adanya pilihan menu vegetarian, maka "In.yo" menjadi tepat untuk menggambarkan bahwa menu yang disebutkan tidak menggunakan bahan yang sebenarnya melainkan bahan substitusi daging.

Selain itu, In.yo juga dapat diartikan dalam bahasa gaul percampuran Inggris dan Jawa, dimana kata "in" kerap diartikan menjadi sesuatu yang sedang trending, mengartikan bahwa In.yo sesuai dengan tren masyarakat yang tengah marak saat ini. Menu-menu In.yo sendiri, dapat dikategorikan kedalam berbagai jenis vegetarian, seperti Lacto-Ovo Vegetarian dan Pescatarian. Namun, berdasarkan jenis vegetarian yang dikategorikan oleh Padmasuri pada tahun 2015, secara keseluruhan, menu In.yo dapat dikategorikan sebagai Pseudo Vegetarian yang merupakan kelompok yang hanya menghindari daging merah, dan masih mengkonsumsi daging ayam serta hewan laut secara rutin. Dalam perjalanan bisnisnya, In.yo juga berusaha untuk mengedukasi konsumennya, yang $90 \%$ merupakan Generasi Z, mengenai banyaknya jenis-jenis vegetarian melalui microblog yang diunggah pada media sosialnya. Hal ini dilakukan karena In.yo menyadari bahwa pengetahuan Generasi Z di Indonesia, terutama di kota Surabaya, Jombang, dan Samarinda mengenai pola makan vegetarian ini masih rendah. Selain itu, dengan menyediakan protein nabati dengan menu dan cita rasa yang sama dengan menu berprotein ayam, dari sini In.yo berusaha mengajak konsumen untuk mencoba berbagai jenis protein yang disediakan, baik unggas, hewan laut, maupun protein nabati. 
Tabel 1.1 Data Penjualan In.yo Selama 5 Bulan

\begin{tabular}{clc}
\hline No & \multicolumn{1}{c}{ Menu } & Jumlah \\
\hline 1 & Special Bibimbap (Mengandung Protein Nabati) & 98 \\
2 & Chik'n n Mushroom Mentai (Mengandung Protein Nabati) & 35 \\
3 & Chicken n Mushroom Mentai & 92 \\
4 & Cheesy Kimchi Fried Rice (Protein Nabati) & 53 \\
5 & Chicken Sweet n Spicy & 30 \\
6 & Chicken Soy Garlic & 13 \\
7 & Chik'n Sweet n Spicy (Mengandung Protein Nabati) & 3 \\
8 & Chik'n Mix Sauce (Mengandung Protein Nabati) & 12 \\
9 & KFMix Soy Garlic (Mengandung Protein Nabati) & 9 \\
10 & KFMix Sweet n Spicy (Mengandung Protein Nabati) & 4 \\
11 & Oyakodon & 49 \\
12 & KFMix Sauce Mix (Mengandung Protein Nabati) & 40 \\
13 & Chicken Mix Sauce & 64 \\
14 & Chik'n Soy Garlic (Mengandung Protein Nabati) & 4 \\
15 & Otteokki & 17 \\
16 & Gimbap Mentai & 34 \\
17 & Gimbap Mozza & 26 \\
18 & Big Gig Box & 11 \\
19 & Cake Mentai & 5 \\
20 & Cake Korean Fried Chicken & 1 \\
\hline
\end{tabular}

Berdasarkan data tabel 1 penjualan In.yo selama 5 bulan (Oktober 2020 - Februari 2021), In.yo telah menjual sebanyak 600 porsi makanan, dimana $45.84 \%$ nya menunjukan penjualan makanan dengan protein nabati dan 54.16\% menunjukan penjualan makanan dengan protein ayam atau ebi. Berdasarkan hasil survei yang telah dilakukan kepada konsumen In.yo, 95\% yang telah membeli produk dengan protein nabati bukan merupakan golongan vegetarian. Hal ini membuktikan bahwa masyarakat tertarik untuk membeli yang mengandung protein In.yo, tidak berdasarkan pola makan mereka, akan tetapi disebabkan oleh beberapa faktor diantaranya, rasa penasaran dan keingintahuan terhadap pola makan vegetarian, ingin hidup sehat, serta keinginan untuk mengikuti trend. Dalam proses penjualannya, In.yo kerap kali melakukan microblog melalui media sosialnya mengenai berbagai fakta mengenai vegetarian serta protein nabati yang disediakan In,yo. Hal ini dilakukan untuk untuk meningkatkan brand eksposure, membangun customer engagement mengedukasi masyarakat terutama konsumennya, serta berusaha untuk mencapai kesadaran konsumen, yang akhirnya dapat mengubah opini, persepsi, dan emosi, konsumen mengenai makanan vegetarian ala Korea sehingga pada akhirnya tertarik melakukan tindakan pembelian. Hal ini juga disebutkan dalam indikator kesadaran konsumen menurut Schiffman dan Kanuk (2004:18).

Persepsi menjadi salah satu dari banyak faktor dapat berpengaruh terhadap intensi manusia dalam memutuskan membeli kebutuhannya (Kotler dan Keller, 2016). Penampilan dan tekstur dari makanan merupakan salah satu faktor yang mempengaruhi pemahaman 
konseptual terhadap makanan tersebut. Pengalaman konsumen terjadi sebagai proses multiindrawi (multisensory process) yang diikuti proses kognitif. Dalam hal ini, proses kognitif berperan pula dalam menciptakan konsep budaya sosial sehingga makanan dapat menjadi objek simbolik yang memberikan identitas pada konsumen (Furaji et.al., 2013) Oleh karena itu dalam mengambil keputusan, manusia tidak lepas dari adanya bantuan persepsi yang berhubungan secara langsung dengan stimulasi panca indra. Sehubungan dengan itu, maka tampilan suatu makanan menjadi penting dalam proses pengambilan keputusan saat membeli makanan. Persepsi konsumen terhadap makanan juga dipengaruhi pengenalan merek toko yang berkualitas. Selain itu Harga juga sangat mempengaruhi keberhasilan produk makanan (Toporowski dan Laderman, 2014). Pengambilan keputusan adalah salah satu mekanisme paling kompleks dalam proses berpikir manusia (Furaji et al., 2013). Keputusan pembelian yang dilakukan oleh konsumen melibatkan pemilihan antara dua atau lebih produk yang akan dipilih. Dalam pengukuran gaya pengambilan keputusan, terdapat alat ukur Consumer Style Inventory (CSI) dari Sproles dan Kendall (1986) untuk mengidentifikasi karakteristik umum gaya pengambilan keputusan konsumen. Maka dari itu dapat dikatakan bahwa kualitas produk, rasa, serta keputusan pembelian konsumen menjadi indikator yang penting dalam penelitian mengenai persepsi konsumen Generasi Z terhadap makanan vegetarian ala Korea pada bisnis rice bowl In.yo.

Maka dari itu dibuatlah penelitian "Persepsi Generasi Z Terhadap Pembelian Makanan Vegetarian ala Korea Pada Bisnis Rice Bowl In.yo" untuk menganalisa dan mengetahui alasan Generasi Z terhadap keputusan pembelian makanan vegetarian ala Korea di Surabaya, ditinjau dari faktor eksternal dan internal yang mempengaruhinya, dengan kualitas produk, rasa dan keputusan pembelian konsumen sebagai indikator yang penting dalam penelitian. Lebih jauh lagi penulis ingin melihat bagaimana persepsi Generasi Z sebagai populasi terbesar di Indonesia saat ini terhadap makanan vegetarian ala Korea yang saat ini tengah menjadi tren makanan menjadi sesuatu yang menarik untuk dianalisa. Masih minimnya pengetahuan masyarakat mengenai aneka jenis pola makan vegetarian, serta usaha In.yo dalam mengedukasi Generasi $\mathrm{Z}$ melalui media sosial juga menjadi salah satu hal yang menarik untuk dibahas dalam penelitian ini.

\section{Metode Penelitian}

Penelitian ini menggunakan metode penelitian deskriptif kualitatif, dasar pemikirannya adalah karena penelitian ini ingin mengetahui tentang fenomena yang ada dalam kondisi alamiah, buatan dalam kondisi terkendali, laboratoris, maupun eksperimen. Penulis menggunakan pendekatan kualitatif untuk mendeskripsikan data yang penulis peroleh sebagai hasil penelitian. Penelitian ini juga termasuk dalam tipe penelitian studi kasus intrinsik, dimana penelitian dilakukan karena ketertarikan pada suatu kasus tertentu, dan didukung dengan studi kasus membantu peneliti memperoleh pemahaman mengenai interelasi berbagai fakta yang ada dalam kasus tersebut. Dalam teknik pengambilan sampel untuk subjek dalam penelitian ini, teknik yang digunakan adalah teknik purposive sampling. Teknik ini melakukan pengambilan sampel sumber data dengan pertimbangan tertentu. Penulis telah menentukan kriteria tertentu dalam memilih informan, antara lain, (1) merupakan Generasi Z (rentang usia 16-24 tahun), (2) konsumen In.yo yang telah 
membeli produk lebih dari satu kali (repeat customer), (3) konsumen In.yo yang membeli produk makanan dengan protein nabati. Informan terpilih juga berasal dari ketiga tempat bisnis In.yo beroperasi yakni di kota Surabaya, Jombang, dan Samarinda. Penulis melakukan observasi partisipan tidak langsung melalui kebiasaan pembelian, serta melakukan wawancara daring karena mengikuti kaidah physical distancing. Dalam penelitian ini, penulis bertindak sebagai key instrument sekaligus sebagai pengumpul data, serta pelaku bisnis. Kehadiran peneliti dalam penelitian kualitatif mutlak diperlukan, terutama sebagai instrumen utama pengumpul data, peneliti terlibat dan melakukan pengamatan, untuk menghasilkan penelitian yang dibagi menjadi tiga tahap, antara lain, (1) Penelitian pendahuluan, guna mengetahui fenomena yang ada serta permasalahan yang ingin dibahas, (2) pengumpulan data, (3) evaluasi data untuk menilai kesesuaian data yang diperoleh dengan realita.

\section{Hasil dan Pembahasan}

\subsection{Pengaruh media sosial terhadap tingkat pengetahuan dan persepsi Generasi $Z$ terhadap makanan vegetarian ala Korea}

Sebagai pola makan, vegetarian sudah terbukti sebagai pola makan yang alami dan sehat bagi tubuh, meskipun begitu masih banyak yang memandang pola makan vegetarian ini sebelah mata (Susianto, dkk., 2007:3) Berdasarkan survei yang dilakukan oleh Fakultas Psikologi Universitas Diponegoro, ada sejumlah respon negatif yang diperoleh dari hasil survei yang menunjukkan rendahnya tingkat pengetahuan Generasi $\mathrm{Z}$ terhadap pola makan vegetarian dan pengaruhnya bagi kesehatan. Sikap konsumen yang positif diperlukan untuk mendorong intensi pembelian, dengan pengetahuan yang cukup terhadap objek yang akan dibeli maka persepsi dan sikap konsumen dapat berubah. Konsumen kerap kali menerima banyak informasi dari sumber-sumber komersial dibandingkan dari sumber pribadi atau publik, meskipun pada keputusan pembeliannya lebih banyak dipengaruhi oleh pribadi dan lingkungan (Boyd dkk., 2000). Biasanya, konsumen akan mengevaluasi informasi yang didapatkan berdasarkan persepsi pribadinya. Persepsi sendiri merupakan pengorganisasian, penginterpretasian terhadap stimulus yang di inderanya sehingga merupakan sesuatu yang berarti dan merupakan respons yang terintegrasi dalam diri individu itu sendiri (Walgito, 2002:69). Dengan adanya informasi tersebut, ditambah dengan informasi mengenai maraknya budaya korea dan meningkatnya kegemaran Generasi $\mathrm{Z}$ terhadap makanan Korea, maka In.yo menciptakan berbagai varian makanan dengan pilihan protein dari ayam, maupun protein nabati dari proteina, dengan cita rasa Korea untuk mendapatkan perhatian dari konsumen, dan meningkatkan ketertarikan konsumen kepada makanan vegetarian ala Korea tersebut. Selain itu, mengetahui bahwa Generasi Z kerap kali menghabiskan banyak waktu di media sosial, dan mendapatkan banyak informasi melalui media sosial, In.yo juga berusaha untuk mengedukasi masyarakat, terutama konsumennya mengenai aneka jenis pola makan vegetarian, serta pilihan-pilihan protein nabati yang disediakan oleh In.yo melalui media sosial Instagram.

Edukasi melalui media sosial dilakukan oleh In.yo, sebab pengetahuan merupakan salah satu faktor penting yang mendorong tindakan seseorang, dalam hal ini yang dimaksud adalah intensi pembelian konsumen. Berdasarkan penelitian yang dilakukan oleh 
Padmasuri pada tahun 2015, terdapat beberapa jenis vegetarian, antara lain :

1. Vegan

Merupakan jenis vegetarian murni. Kelompok ini tidak mengkonsumsi produk hewani jenis apapun, termasuk madu, serta produk kosmetik yang di tes pada hewan maupun pakaian yang menggunakan kulit hewan.

2. Lacto Vegetarian

Merupakan jenis vegetarian yang mengkonsumsi protein nabati saja, namun masih mengkonsumsi susu dan seluruh hasil olahan susu seperti keju, dan yougurt.

3. Ovo Vegetarian

Merupakan jenis vegetarian yang mengkonsumsi protein nabati saja, dan menghindari produk olahan susu, namun masih mengkonsumsi telur.

4. Lacto-ovo Vegetarian

Merupakan jenis vegetarian yang mengkonsumsi protein nabati saja, namun masih mengkonsumsi telur, susu, dan produk olahannya.

5. Pseudo Vegetarian

Merupakan jenis vegetarian yang hanya menghindari daging merah saja, dan masih mengkonsumsi daging ayam, dan daging ikan secara rutin.

6. Pollo Vegetarian

Merupakan jenis vegetarian yang masih mengkonsumsi daging unggas, namun tidak mengkonsumsi daging lainnya.

7. Pesco Vegetarian

Dapat disebut juga sebagai pescatarian. Merupakan jenis vegetarian yang menghindari segala jenis protein daging, namun masih mengkonsumsi ikan.

8. Semi Vegetarian atau Flexitarian

Merupakan jenis vegetarian yang tidak rutin mengkonsumsi daging, namun bebas mengkonsumsi jenis protein apapun.

\section{Frutarian}

Merupakan jenis vegetarian yang tidak mengkonsumsi protein daging apapun, dan menjadikan buah-buahan sebagai makanan sehari-hari.

Berdasarkan jenis vegetarian di atas, In.yo secara keseluruhan masih dapat digolongkan sebagai Pseudo Vegetarian, menu In.yo juga dilengkapi dengan tanda Lacto Vegetarian, Lacto-Ovo Vegetarian, dan Pescatarian pada setiap menunya guna edukasi bagi konsumen. Banyak konsumen yang mengaku tidak mengetahui mengenai istilah- istilah tersebut sebelumnya, salah satu informan mengaku hanya mengetahui Vegan dan vegetarian sebelumya, "Setauku sih cuma ada dua jenis, vegan itu yang ngga boleh makan telur sama susu dan keju, kalau vegetarian itu masih boleh, itu aja sih" (Wawancara dengan Yogi, 1 Februari 2021) saat ditanya mengenai pengetahuan istilah jenis vegetarian sebelum membaca Informasi yang dibagikan oleh In.yo melalui media sosial dalam bentuk microblog. Selain untuk melakukan edukasi bagi konsumennya, In.yo juga mengunggah banyak microblog guna meningkatkan kesadarkan konsumen, In.yo ingin konsumen potensialnya memiliki pemahaman yang cukup mengenai brand In.yo dan produk yang ditawarkannya untuk dapat menerima dan menanamkannya dalam pikiran mereka setiap 
ingin membeli produk makanan Korea maupun makanan vegetarian ala Korea. Indikator kesadaran konsumen juga dipaparkan oleh Schiffman dan Kanuk (2004:18):

1. Perubahan opini

Perubahan yang terjadi ketika konsumen mendapatkan rekomendasi maupun pendapat mengenai produk dari pengguna sebelumnya.

2. Perubahan persepsi

Perubahan yang dirasakan oleh konsumen saat terdapat suatu persamaan minat dalam produk yang didukung oleh faktor seperti pengalaman pengguna lain, maupun keunikan dari produk tersebut.

3. Perubahan emosi

Perubahan yang dirasakan saat perasaan konsumen berubah melalui kertarikannya terhadap tampilan dari produk yang ditawarkan

4. Tindakan pembelian

Hasil akhir dari proses kesadaran konsumen, pengkombinasian opini, persepsi dan emosi terhadap produk sehingga konsumen melakukan pembelian.

Saat seorang konsumen yang tidak menjalankan pola makan tertentu, seperti vegetarian, dihadapkan pada pilihan makanan vegetarian, tentu saja akan ada keraguan dalam diri konsumen, terutama saat konsumen tidak mengenali pola makan tersebut, serta tidak mengetahui bahan-bahan apa yang digunakan, tekstur, dan rasanya. Maka untuk menarik konsumen untuk melakukan tindakan pembelian, diperlukan suatu edukasi melalui media sosial, untuk memperkenalkan kepada konsumen produk yang ditawarkan oleh In.yo, sehingga memberikan gambaran yang jelas mengenai produk, dan keempat indicator dalam kesadaran konsumen dapat terjadi. Selain jenis-jenis vegetarian, edukasi lainnya yang diberikan oleh In.yo adalah protein nabati yang menjadi alternatif dari daging ayam pada berbagai menu In.yo. Untuk protein nabati yang digunakan oleh In.yo sendiri adalah proteina. Proteina merupakan olahan yang terbuat dari jagung dan memiliki rasa yang gurih, proteina memiliki tiga pilihan bentuk yaitu berbentuk cincang, kasar dan irisan (Rossi, 2012). Salah satu menu yang paling banyak terjual dan paling digemari oleh konsumen In.yo adalah "Special Bibimbap". Menu ini terjual sebanyak 98 porsi dalam kurun waktun 5 bulan dari 600 porsi yang dijual oleh In.yo. Bibimbap sendiri merupakan masakan korea berupa nasi putih dengan sayur-sayuran, daging sapi, telur, dan saus pedas gochujang di atasnya, secara harafiah diartikan sebagai nasi campur, dan dimakan dengan cara diaduk menjadi satu.Dinamakan special karena protein pada Bibimbap umumnya adalah daging sapi cincang dengan cita rasa manis gurih yang disebut rasa "bulgogi" di Korea. Namun, pada menu ini, In.yo menggunakan proteina yang dibumbui dengan cita rasa korea, dan diolah secara khusus. Rasa proteina pada menu ini sangat menarik, karena banyak mengelabui konsumen. Banyak konsumen yang tidak menyadari bahwa protein yang dikonsumsinya bukanlah daging sapi cincang, karena tekstur dan rasa yang menyerupai. Dengan disampaikannya informasi tersebut, maka persepsi konsumen dan opini konsumen yang awalnya ragu atau takut terhadap pilihan makanan vegetarian, dapat berubah menjadi rasa penasaran maupun ketertarikan terhadap produk tersebut.

Hal ini disampaikan beberapa kali oleh konsumen In.yo, bahwa setelah 
mengkonsumsinya pertama kali, sama sekali tidak ada pemikiran bahwa protein yang dimakannya bukanlah daging sapi cincang melainkan proteina, meskipun informasi ini telah disampaikan sebelumnya. Mayoritas konsumen justru melakukan pembelian kembali karena sangat menyukai rasanya. Hal ini juga ditanyakan kepada informan yang telah membeli menu "Special Bibimbap" ini lebih dari dua kali, yakni Alesya Firmawan Panghegar, mengenai alasannya membeli kembali "Special Bibimbap" ala In.yo "Pertama kali membeli karena penampilannya sangat menarik di Instagram, lalu saat mencoba pertama kali, entah karena lapar atau bagaimana, tapi rasanya pun sangat lezat, apalagi dagingnya. Memang aku tidak pernah mengenal protein yang vegetarian sebelumnya, jadi saat makan aku pikir itu daging sapi. Mungkin karena dibumbui dengan baik, dan teksturnya yang mirip daging cincang, apabila tidak benar-benar diperhatikan, aku rasa akan sulit untuk orang tahu bahwa itu vegetarian, dan menurutku itu adalah hal yang baik sih, terutama buat kita yang bukan vegetarian ya.'(Wawancara dengan Alesya, 1 Februari 2021). Hal ini juga didukung oleh pendapat dari Johanes Chrisna Putra, "Menurutku dagingnya enak dan memang tidak terasa seperti bukan daging sapi, ya rasanya seperti daging sapi, mungkin bentuknya bulatnya rapi gitu ya, hanya saja karena belum pernah tau makanan vegetarian, aku juga tidak bisa mengidentifikasi ini apa, kalau misal bukan daging cincang". (Wawancara dengan Johanes, 1 Februari 2021). Berdasarkan pendapat dari para informan, dapat disimpulkan bahwa tingkat pengetahuan konsumen Generasi Z, masih sangat rendah mengenai jenis vegetarian maupun protein pengganti yang digunakan, namun melalui media sosial, hal tersebut dapat berubah, persepsi konsumen yang bukan golongan vegetarian terhadap makanan vegetarian dapat berubah menjadi positif, selain itu In.yo sebagai brand dapat memperkenalkan produk dan keunikan yang dimilikinya,melakukaan engagement dengan konsumen maupun calon konsumen, serta melakukan edukasi terhadap konsumen potensial agar konsumen dapat memahami produk tersebut dan melakukan penerimaan terhadap produk, dapat meningat dan menanamkan dalam pikirannya ketika ingin makanan vegetarian ala Korea. Untuk mencapai hal tersebut, perlu terdapat 4 indikator kesadaran konsumen, yakni perubahan opini, perubahan persepsi, perubahan emosi, sebelum akhirnya melakukan tindakan pembelian (Schiffman dan Kanuk, 2004).

\subsection{Persepsi Konsumen dan Faktor-Faktor Yang Mempengaruhi Keputusan Pembelian Produk Vegetarian In.yo}

Konsumen pada umumnya akan mengambil keputusan untuk melakukan pembelian suatu produk diawali dengan kesadaran atas pemenuhan kebutuhan dan keinginannya (Sustina, 2001). Konsumen juga kerap kali memiliki intensi untuk mencari informasi dan mengabarkan pada teman, kerabat, maupun pihak lain mengenai pengalamannya (Mowen $\&$ Minor, 2002). Dalam membeli makanan vegetarian, intensi konsumen dapat dipengaruhi oleh banyak sekali hal yang dapat dikategorikan menjadi empat, yakni faktor budaya, faktor sosial, faktor pribadi, dan faktor psikologis. Masing-masing faktor memiliki pengaruhnya sendiri dalam mendorong intensi pembelian konsumen (Kotler, 2004).Seiring berkembangnya zaman, makanan sehat dan makanan vegetarian mulai diminati oleh remaja terutama generasi Z. Ketika memutuskan untuk membeli produk rice bowl yang 
mengandung protein nabati, setiap informan memiliki alasan atau faktor yang berbedabeda antara yang satu dengan yang lainnya. Hal ini terungkap saat peneliti bertanya kepada informan, "Apa yang membuat informan akhirnya memutuskan untuk membeli produk vegetarian In.yo?", Alesya menjawab bahwa muncul rasa penasaran dan ketertarikan untuk mencoba produk vegetarian In.yo (Wawancara dengan Alesya, 1 Februari 2021). Disampaikan juga oleh Alesya bahwa ia bukan merupakan golongan vegetarian, serta saat mendapat edukasi dari Instagram In.yo, rasa ketertarikan untuk mencoba makanan vegetarian dan pengetahuan seputar vegetarian bertambah (Wawancara dengan Alesya, 1 Februari 2021).

Informan kedua, Johanes, menjelaskan bahwa faktor yang mendorong ia untuk membeli produk vegetarian In.yo karena harga menu produk vegetarian yang In.yo tawarkan cenderung lebih murah dibanding produk non-vegetarian (Wawancara dengan Johanes, 1 Februari 2021). Diakui oleh Johanes, bahwa ia bukan merupakan golongan vegetarian (Wawancara dengan Johanes, 1 Februari 2021).

Agus, informan ketiga menyampaikan bahwa ia merasa bosan dengan makanan dirumahnya dan belum pernah mencoba makanan vegetarian, sehingga ia penasaran dengan rasa makanan vegetarian (Wawancara dengan Agus, 11 Februari 2021). Agus juga bukan dari golongan vegetarian, ujarnya. (Wawancara dengan Agus, 11 Februari 2021).

Informan keempat, Yogi, yang bukan merupakan golongan vegetarian dan disampaikan alasan yang memutuskan untuk membeli produk vegetarian karena ia sedang dalam diet, selain itu, Yogi juga mendapat rekomendasi mengenai produk vegetarian In.yo dari teman satu kampusnya (Wawancara dengan Yogi, 8 Februari 2021).

Dari beberapa penelitian yang sudah dilakukan, hasil yang didapat menunjukan bahwa makanan vegetarian lebih sehat dibandingkan makanan non-vegetarian. Tubuh memerlukan asupan karbohidrat, protein, minyak, serat dan hal ini dapat diperoleh oleh orang vegetarian yang mengkonsumsi makanan dari protein nabati. Mengkonsumsi makanan vegetarian dapat mengurangi resiko penyakit seperti jantung dan liver (Chandra, 2009). Pola makan vegetarian tidak jauh dari pola makan yang mengkonsumsi makanan tinggi serat (Khomsan, 2006).

Keputusan pembelian merupakan tahap dalam proses pengambilan keputusan pembelian dimana konsumen benar-benar membeli. Pengambilan keputusan adalah suatu kegiatan individu yang secara langsung dan terlibat dalam mendapatkan dan mempergunakan barang yang ditawarkan (Kotler \& Armstrong, 2004).

Adapun dari hasil wawancara yang telah dilakukan, faktor-faktor yang mempengaruhi seseorang untuk membeli produk vegetarian In.yo didasari rasa ingin tau, harga yang cenderung lebih murah dibandingkan menu dengan protein ayam, menjalankan program diet, mendapatkan rekomendasi dari teman, serta yang menjadi bagian terpenting adalah adanya usaha dari In.yo untuk memberikan edukasi seputar makanan vegetarian dan macam-macam jenis/bentuk vegetarian (Gambar 3.1 dan Gambar 3.2) 


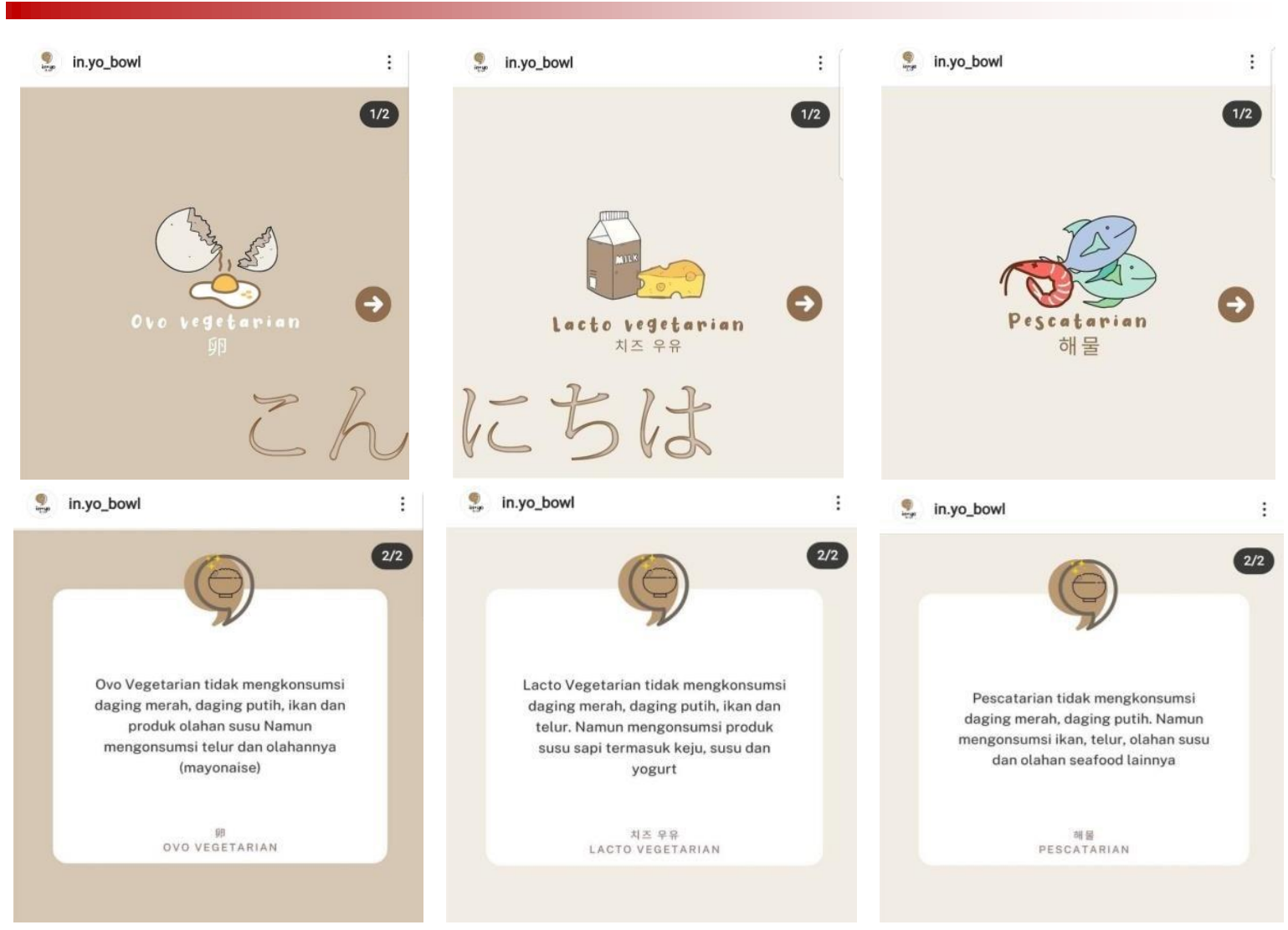

Gambar 3.1 Edukasi Vegetarian pada Instagram In.yo

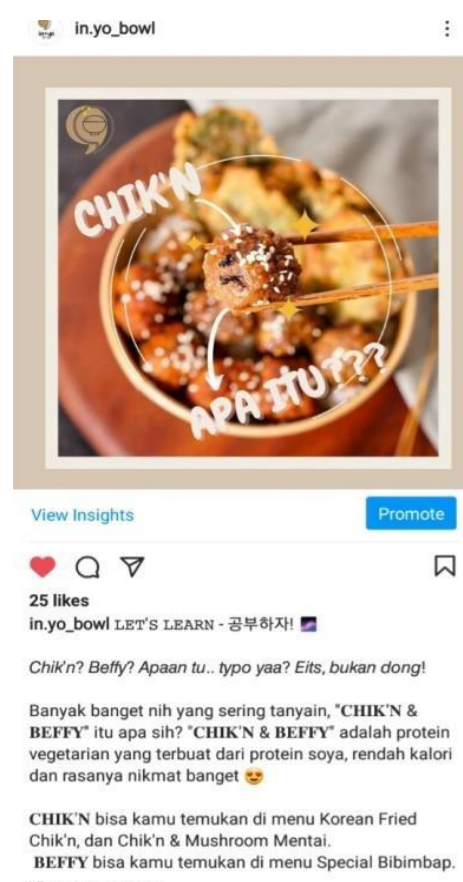

Gambar 3.2 Edukasi Vegetarian pada Instagram In.yo

Dari wawancara yang sudah dilakukan, terdapat konsumen yang rasa ketertarikannya meningkat (Wawancara dengan Alesya, 1 Februari 2021), yang dirasa hal ini merupakan hal yang baik, dimana ketika membeli sebuah produk makanan tidak hanya membawa produk makanannya, melainkan mendapat bekal edukasi dari In.yo. 


\section{Kesimpulan}

Berdasarkan hasil survei yang telah dilakukan kepada konsumen In.yo, 95\% yang telah membeli produk dengan protein nabati bukan merupakan golongan vegetarian. Masyarakat tertarik untuk membeli yang mengandung protein nabati In.yo, tidak berdasarkan pola makan mereka, akan tetapi disebabkan oleh beberapa faktor diantaranya, rasa penasaran dan keingintahuan terhadap pola makan vegetarian, ingin hidup sehat, serta keinginan untuk mengikuti trend. Meskipun konsumen tidak menjalankan pola hidup vegetarian jenis apapun. Intensi membeli makanan vegetarian merupakan kecenderungan yang mengarahkan seseorang untuk merencanakan pembelian.

Generasi $\mathrm{Z}$ meskipun memiliki pengetahuan yang sangat rendah mengenai jenis- jenis vegetarian maupun protein nabati sebagai alternatif daging, memiliki intensi pembelian makanan vegetarian ala Korea karena rasa penasaran ingin mencoba karena melihat iklan yang ada di media sosial, ingin menurunkan berat badan,serta karena harga yang lebih murah dibandingkan dengan menu berprotein daging ayam. Usaha In.yo untuk mengedukasi Generasi $\mathrm{Z}$ mengenai pola makan vegetarian melalui media sosial, serta menyediakan pilihan makanan vegetarian memiliki pengaruh besar untuk mengubah persepsi Generasi $Z$ terhadap makanan vegetarian ala Korea.

\section{Ucapan Terimakasih}

Ucapan terimakasih kepada :

- Tuhan Yang Maha Esa atas segala rahmat dan karunia-Nya yang memberikan kekuatan bagi peneliti selama penelitian ini berlangsung.

- Alesya Firmawan Panghegar, Johanes Chrisna, Yogi, dan Agus Salim sebagai narasumber yang bersedia memberikan waktu dan informasi guna membantu kelancaran penelitian.

- Seluruh tim In.yo sebagai informan utama yang bersedia memberikan data yang berguna untuk menunjang penelitian.

\section{Pustaka}

Anonim. 2020. Tumbuh 20\%, Berikut Tren Bisnis Kuliner di Surabaya. https://gobiz.co.id/pusat-pengetahuan/bisnis-kuliner-surabaya/. Diakses 30 Januari 2021.

Boyd, H.W., Walker, O.C \& :arrenche, J.C.2000. Manajemen Pemasaran: Suatu Pendekatan Strategis dengan Orientasi Global. Jilid 1. Alih bahasa: Imam Nurmawan. Jakarta: Erlangga.

Chandra, Y. (2009). Hidup Sehat dengan Makanan Vegetarian. http://www.kaltimpost.co.id/?mib=berita.detail\&id=33125 Diakses pada tanggal 2 Februari 2021.

Fer. 2020. Generasi Z Dominasi Pengguna Internet Selama Pandemi Covid-19. https://www.beritasatu.com/digital/654827/generasi-z-dominasi-penggunainternet-selama-pandemi-covid19 Diakses 30 Januari 2021.

Furaji, F., Latuszyńska, M., Wawrzyniak, A., \& Wasikowska, B. (2013). Study on the 
influence of advertising attractiveness on the purchase decisions of women and men. Journal of International Studies. 6(2), 20-32. DOI: 10.14254/20718330.2013/6- 2/2.

Hendrika, Agnesia. 2011. Dinamika Kongnitif Kaum Vegan. Surabaya :Fakultas Psikologi Universitas Widya Mandala .

Kementrian Perindustrian Republik Indonesia. 2018. Jadi Prioritas Industri 4.0, Lima Sektor Ini Berkontribusi 60 Persen untuk PDB. https://kemenperin.go.id/artikel/19231/Jadi-Prioritas-Indutri-4.0,-Lima-Sektor-IniBerkontribusi-60-Persen-untuk-PDB Diakses 30 Januari 2021.

Khomsan, A. (2006). Solusi Makanan Sehat. Jakarta: PT Raja Grafindo Persada.

Kotler, P., \& Amstrong, G. (2004).Principles of marketing (10th ed.). New Jersey: Prentice Hall. Inc.

Kotler, Philip dan Keller, Kevin Lane. 2016. Marketing Management. 15th Edition. New York: Pearson Education Limited. 2002. Manajemen Pemasaran. Jilid 1. Alih Bahasa: Benjamin Molan. Jakarta: Prenhallindo.

Maslow, Abraham. Tanpa Tahun. Motivation and Personality (Teori Motivasi dengan Ancangan Hirarki Kebutuhan Manusia). Terjemahan Oleh Nurul Iman. 1984. Jakarta: PT Gramedia.

Mowen, J.C \& Minor, M. 2002. Perilaku Konsumen. Alih bahasa: Dwi Kartini Yahya. Jakarta: Erlangga.

Neti, Sisira. 2011. Social Media and Its Role in Marketing. International Journal of Enterprise Computing and Business Systems. 1(2):1-6.

Padmasuri, Karina. 2015. I'm a Happy Vegetarian, Gaya Hidup dengan Resep-Resep Vegetarian Pilihan. Yogyakarta: OCTOPUS Publishing House

Putri, Karina Amaliantami. Amirudin, dan Mulyo Hadi Purnomo. 2019. Korean Wave dalam Fanatisme dan Konstruksi Gaya Hidup Generasi Z. Nusa.Vol 14(1):128129.

Rossi, Ara. 2012. Vegetarian. Yogyakarta: G-Media

Salvatore, Dominick. 2005. Managerial Economics. Fifth Edition. Singapore: Thomson Learning.

Sawyer, Stacey. C \& Williams, Brian K. 2001. Using Information Technology. New York: McGraw-Hill Company.

Schiffman, L.G. dan Leslie Lazar Kanuk. 2004. Perilaku Konsumen. Alih Bahasa: Soleh Rusyadi M. Jakarta:PT. Indeks Group Gramedia

Sproles, G.B., \& Kendall, E.L. 1986. A methodology for rofiling consumers decision making styles. The Journal of Consumer Affairs. 20(2):267-79

Sumarwan, Ujang. 2002. Perilaku Konsumen (Teori dan Penerapannya dalam Pemasaran). Bogor: Ghalia Indonesia.

Susianto, Widjaja, H. \& Mailoa, H.J. 2007. Diet Vegetarian. Jakarta: Niaga Swadaya.

Susilawati, Desy. 2020. Ingin Berlaih pada Makanan Nabati? Pahami Dulu Hal Ini. https://www.republika.co.id/berita/qlhgl2425/ingin-beralih-pada-makanan-nabatipahami-dulu-hal-ini. Diakses pada 4 Februari 2021.

Sustina. 2001. Perilaku Konsumen dan Komunikasi Pemasaran. Bandung: PT Rosdakarya 
Toporowski, W. dan Lademann, R. 2014. The Importance of Assortment, Pricing, and Retail Site Location for Competition in Food Retailing - Results from Marketing Research, Marketing, ZFP, Quartal2014.http://www.lademannassociates.de/images/docs/The_Importance_of_Assortment,_Pricing,_ and_Retail_Site_Location_for_Competition_in_Food_Retailing.pdf.Diakses Februari 2021

Trihendrawan, Nuriwan. 2019. Sektor Kuliner Indonesia Tumbuh $12,7 \%$. https://ekbis.sindonews.com/berita/1388028/34/sektor-kuliner-indonesia-tumbuh127? showpage=all Diakses pada 30 Januari 2021.

Walgito, B. 2002. Pengantar Psikologi Umum. Yogyakarta : Andi Yogyakarta.

Wijoyo, Hadion, dkk. 2020. Generasi Z \& Revolusi Industri 4.0. Banyumas: CV. Pena Persada. 